\title{
The metabolic cost of maintaining a synapse during development
}

\author{
Jan Karbowski ${ }^{1,2}$ \\ From Twenty Second Annual Computational Neuroscience Meeting: CNS*2013 \\ Paris, France. 13-18 July 2013
}

\section{Background}

Experimental data indicate that cerebral energy consumption and synaptic density qualitatively correlate during development [1,2], presumably indicating that energy plays a key role during the process. The purpose of this study is two-fold. First, to collect empirical data on cortical metabolism and synaptic density during development (from birth to adulthood for different mammals), and to quantify their dependence. Second, to provide atheoretical link between neural metabolism and electrical activities of neurons and synapses [3]. A theoretical model allows us to estimate synaptic contribution to the overall energy used by neurons.

\section{Results}

It is found that regional metabolic rate per synapse is approximately conserved from birth to adulthood for a given species (rat, cat, macaque, human). A typical synapse uses about 7000 glucose molecules per second in primate cerebral cortex, and about 5 times of that amount in cat and rat visual cortices [4]. Based on the theoretical model it is found that synaptic efficacy is generally inversely correlated with average firing rate, and additionally, synapses consume a bulk of metabolic energy, roughly $50-90 \%$ during most of the developmental process (except human temporal cortex $<50 \%$ ) [4]. Overall, these results suggest a tight regulation of brain electrical and chemical activities during the formation and consolidation of neural connections. This presumably reflects strong energetic constraints on brain development [4].

\begin{abstract}
Acknowledgements
The work was supported by the Polish Ministry of Science and Education (grant NN 518 409238).
\end{abstract}

\section{Author details}

${ }^{1}$ Institute of Biocybernetics and Biomedical Engineering, Polish Academy of Sciences, Warsaw, Poland. 'Institute of Applied Mathematics and Mechanics, University of Warsaw, Warsaw, Poland.

\section{Published: 8 July 2013}

\section{References}

1. Huttenlocher PR, Dabholkar AS: Regional differences in synaptogenesis in human cerebral cortex. J Comp Neurol 1997, 387:167-178.

2. Chugani HT: A critical period of brain development: Studies of cerebral glucose utilization with PET. Preventive Medicine 1998, 27:184-188.

3. Karbowski J: Thermodynamic constraints on neural dimensions, firing rates, brain temperature, and size. J Comput Neurosci 2009, 27:415-436.

4. Karbowski J: Approximate invariance of metabolic energy per synapse during development in mammalian brains. PLOS ONE 2012, 7:e33425.

doi:10.1186/1471-2202-14-S1-P203

Cite this article as: Karbowski: The metabolic cost of maintaining a synapse during development. BMC Neuroscience 2013 14(Suppl 1):P203.

\footnotetext{
Correspondence: jkarbowski@duch.mimuw.edu.pl

${ }^{1}$ Institute of Biocybernetics and Biomedical Engineering, Polish Academy of Sciences, Warsaw, Poland

Full list of author information is available at the end of the article
}

Submit your next manuscript to BioMed Central and take full advantage of:

- Convenient online submission

- Thorough peer review

- No space constraints or color figure charges

- Immediate publication on acceptance

- Inclusion in PubMed, CAS, Scopus and Google Scholar

- Research which is freely available for redistribution
C Biomed Central

(c) 2013 Karbowski; licensee BioMed Central Ltd. This is an Open Access article distributed under the terms of the Creative Commons Attribution License (http://creativecommons.org/licenses/by/2.0), which permits unrestricted use, distribution, and reproduction in any medium, provided the original work is properly cited. 